10IKC-094

\title{
MINERALOGY OF MAGMACLASTS AND INTERCLAST MATRICES OF KIMBERLEY-TYPE PYROCLASTIC KIMBERLITES FROM THE KAO, LETSENG-LA-TERAE, LETHLAKANE AND PREMIER KIMBERLITE PIPES IN SOUTHERN AFRICA
}

\author{
Mitchell*a, RH, Scott Smith ${ }^{\mathrm{b}}$, BH, and Skinner ${ }^{\mathrm{c}}$ EMW \\ *a Lakehead University, Thunder Bay, Ontario, Canada (rmitchel@lakeheadu.ca), ${ }^{b}$ Scott-Smith Petrology Inc., North \\ Vancouver, B.C.,Canada, ${ }^{c}$ Rhodes Univesity, Grahamstown, South Africa
}

A particular assemblage of magmaclasts (aka pelletal lapilli) and type of interclast matrix are characteristic features of Kimberley-type pyroclastic kimberlites (KPK; aka tuffisitic kimberlites). This specific textural variety of kimberlite forms the dominant infill of the diatreme zone of a certain type of kimberlite pipe (Class 1) which are common in southern Africa but also occur elsewhere in the world. Regardless of their widespread occurrence, little is actually known regarding their detailed petrographyand mineralogy. This studypresentstextural and mineral compositional data for the magmaclasts and interclast matrices for KPK from the diatreme zone of the following southern African kimberlites: Letlhaka ne; Premier; Letseng-la-terae; and Kao. Samples from the latter include the Gritty (formerly K1) kimberlite from which "pelletal lapilli" were first described by Clement 1973). Back-scattered electron images show that magmaclasts and in terclast matrices are petrographically very similar to each other, regardless of locality or age, and to previously reported examples from Wesselton (Mitchell et al. 2009); the type area of Kimberley-type pyroclastic kimberlite.

Typically magmaclasts consist of a kernel of pseudomorphed macrocrystal olivine and a microcrystalline groundmass of variable thickness composed predominantly of microcrystalline diopside, phlogopite, and apatite with lesser perovskiteand spinel. Although relict fresh olivine is present in some magmaclasts, the macrocryst kernels are typically replaced by several compositionally distinct generations of serpentine and/or chlorite. This multi-generational replacement cannot be the result of secondary processes unrela ted to magmaclast formation as phlogopite in the microcrystalline groundmass surrounding the olivine kernels is not altered to chlorite. The replacement must rath er represent one or more phases of deuter ic alt eration prior to the formation of the magmaclast groundmass. The Kao Gritty kimberlite has textural cha racteristics of being transitional to hypabyssal kimberlite rather being a bona fide KPK

The outer margins of KPK magmaclasts are diffuse and grade into the interclast areas being mantled and decorated by microcrystalline prismatic diopside and/or mica; with some magmaclasts exhibiting modal zoning of these minerals. Interclast matrices in all kimberlites studied are dominated by chlorite with lesser diopside microlites. The chlorite in the interclast matrix is associated with relict phlogopite and is undoubtedly derived by the al tera tion of this mineral. Importantly this episode of chloritization did not affect micas in the magmaclasts and must have occurred subsequent to magmaclast formation. The common diopside of the magmaclast groundm ass and mantles is considered to be a primary crystallizing phase and cann ot be a secondary mineral unrelated to the kimberlite magma as: (1) country rock basalt xenoliths adjacent to diopsidebearing magmaclasts lack diopside mantles; and (2) diopside cannot form at low temperatures from externally derived unrela ted aqueous fluids. None of the interclast textures are typical of secondary replacement as observed in other diatreme infills such as those of the so-called Class 3 kimberlites and melilitites. It is considered impossible that the similar character of Kimberley-type-type pyroclastic rocks, on either a local, regional or world-wide basis, is the result of secondary alter ation by externally-derived unrela ted fluids, as such fluids are extremely unlikely to have a common composition and style of replacement ofany pre-existing consolidated rocks. 
Representative optical and back-scattered electron images of the KPK investigated are given below to illustrate the character of the magmaclast and interclast assemblages.

\section{KAO GRITTY KIMBERLITE}

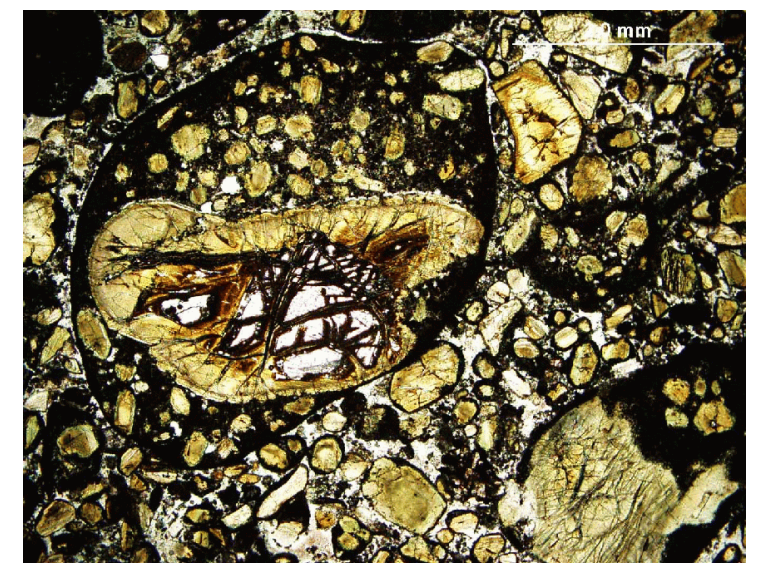

Figure 1

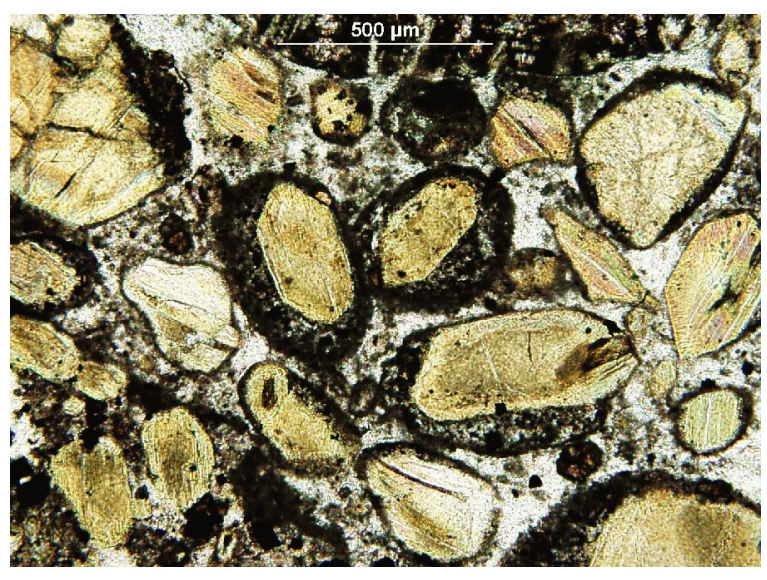

Figure 2

Figure 1. Large magmaclast with relict fresh macrocrystal olivine kernel together with smaller subhedral serpentinized and chloritized olivines set in an optically un-resolvable matrix.

Figure 2. Typical "pelletal lapilli: as described by Clement(1973) consisting of core of euhedral-to-subhedral olivine set in an optically un-resolvable groundmass.

Figure 3

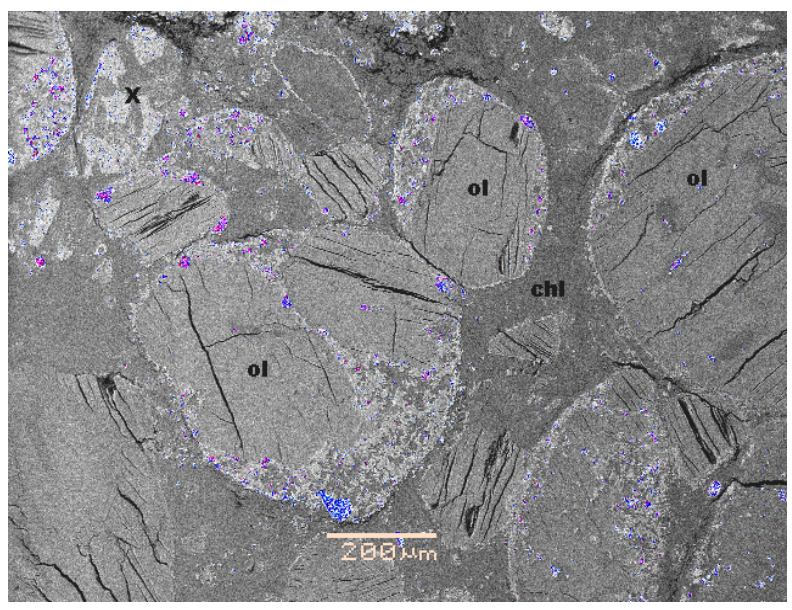

Figure 4

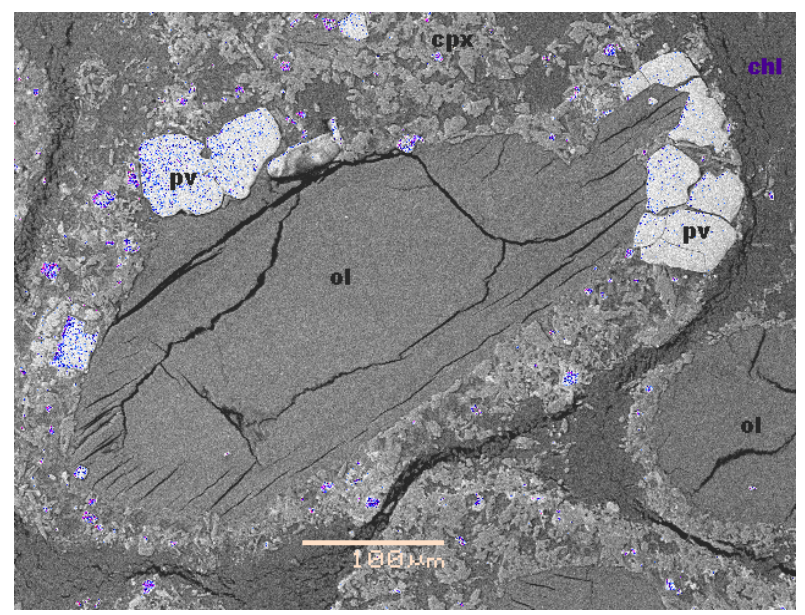

Figure 3. Typical magmaclasts with pseudomorphed olivine (ol)cores and mant le cons isting main ly of diopside (grey), and phlogopite with apati te and perovskite. Also present is a clast of altered basalt which lacks any fring ing diopside. Interclast matrix is composed principally of chlorite (chl)

Figure 4. Magmaclast with a core consisting of an intergrowth of perovskite (pv) and pseudomorphed olivine (ol). Mantle consists of diopside (cpx) and phlogpite (dark grey). 


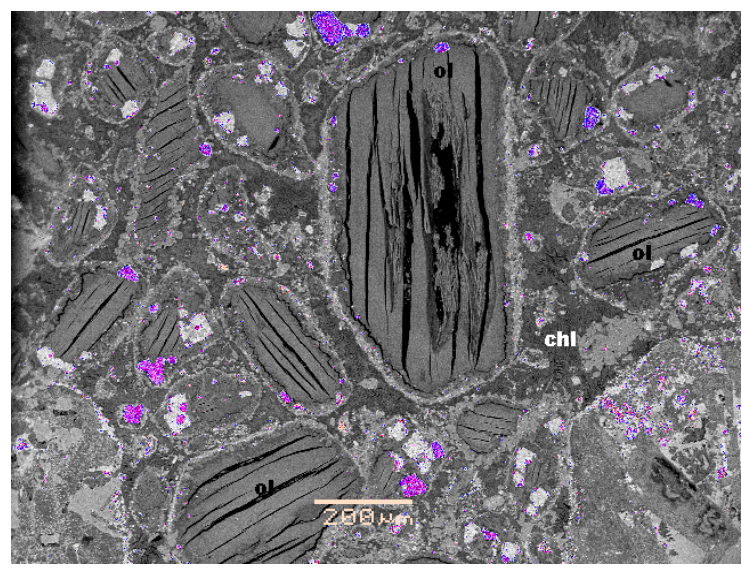

Figure 5

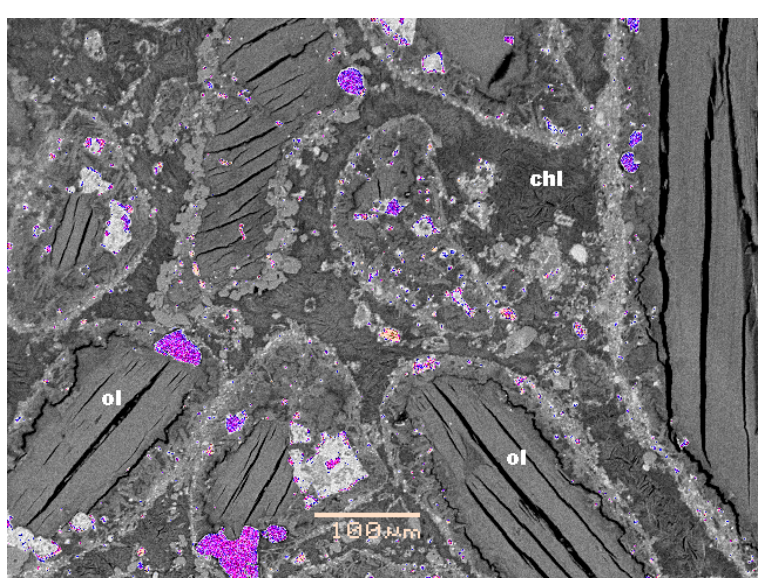

Figure 6

Figure 5. Pseudomorphed olivines (ol) mantled by aggregates composed dominantly of microcrystalline diopside with fresh phlogopite (see Fig 7). Also present are perovskite (purple) and hydroandradite plus titanite (white).

Figure 6. Detail of figure 6 showing mantles of microcrystalline diopside on pseudomorph ed olivine. Also present are perovskite (purple) and hydroandradite plus titan ite (white). The in terclast matrix is composed dominantly of chlorite with relict phlogopite and minor diopside

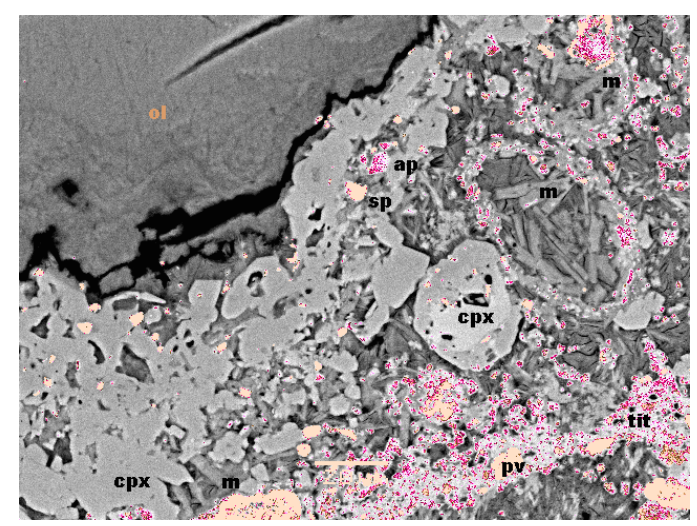

Figure 7. Detail of mantle surrounding a pseudomorphed olivine. Note the presence of abundant prismatic phlogopite (m) set in a chlorite matrix (dark grey). Also present are apatite (ap), spinel (sp), perovskite (pv) and titanite (tit; purple areas) .

It is not possible for the chlorite of the matrix to be introduced by secondary processes unrelated to the genesis of this KPK as the primary phlogopites would have be replaced by such a process.

\section{LETSENG-LA-TERAE}

Figure 8. Magmaclasts in Letseng KPK.

Note the different sizes and extent of development of the diopside-phlogopite mantles. The interclast-matrix is composed of chloritized phlogopite and alumin ous chlorite.

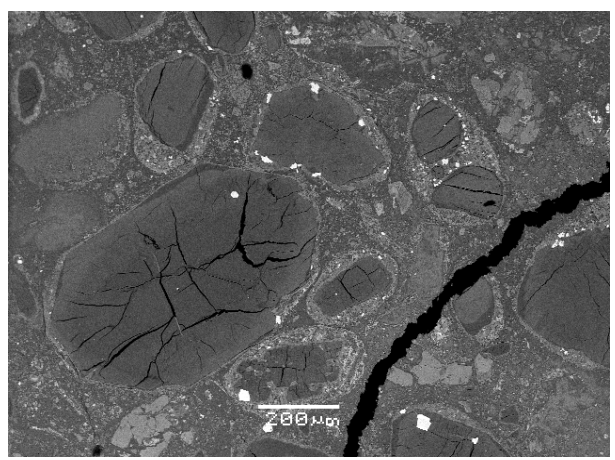

Figure 8 
Figure 9. Interclast matrix in Letseng KPK.

Olivine ma crocrysts are pseudom orph ed by two gen erations of chlorite and mantled by microcrystalline diopside and fresh phlogopite. The mantles are gradational into interclast chlorite-3 and lesser amounts of microcrystalline diopside

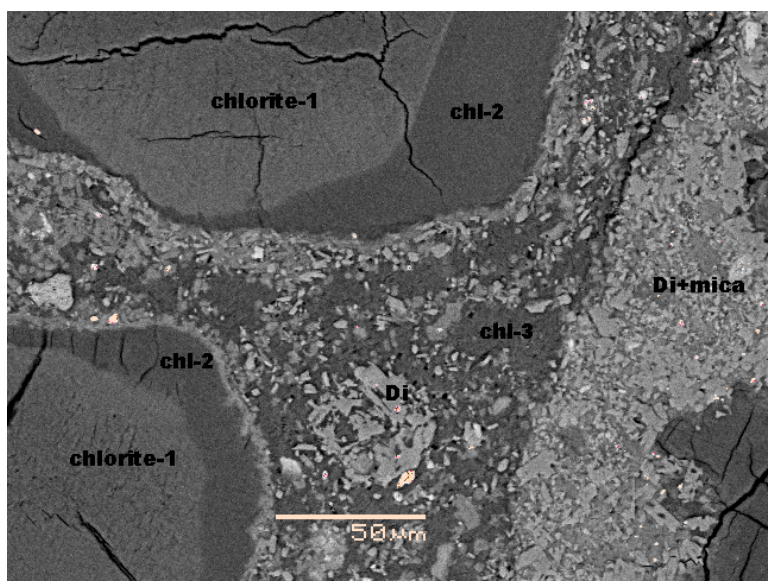

Figure 9

Figure 10. Cryptocrystalline mantle around olivine macrocryst in Letseng KPK.

Mantle composed of diopside (cpx), fresh phl ogopite (m), and tita nite ( $\mathrm{t}$ ) developed on a chloritized olivine macrocryst (CHL-1). Other minerals in the mantle are perovskite and magnetite (white). Interclast matrix is composed dominantly of chlorite (CHL-2).

Figure 11. Interclast matrix, Letseng KPK.

Interclast ma trix consists of diopside (cpx), fresh and partially chloritized phlogopite, with garnet, (g), set in a chlorite mesostasis (chl-2). The garnet is composed of a hydroandradite core (light grey) and a hydro-andradite-grossular rim.

Note the successive developm ent of zones of cryprocrystalline diopside (cpx) and fresh phlogopite $(\mathrm{m})$ on the chloritzed olvine macrocryst (chl-1). The cryptocrystallin e mica has the same composition as the interclast phlogopite.

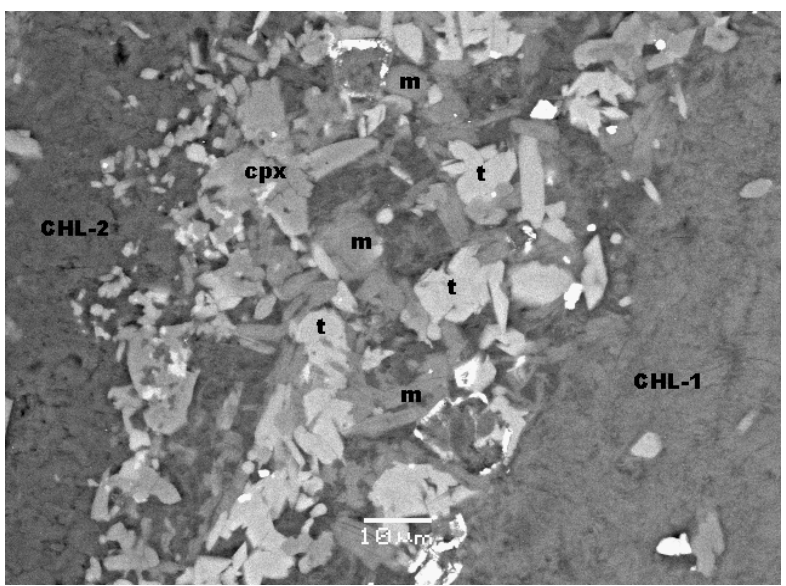

Figure 10

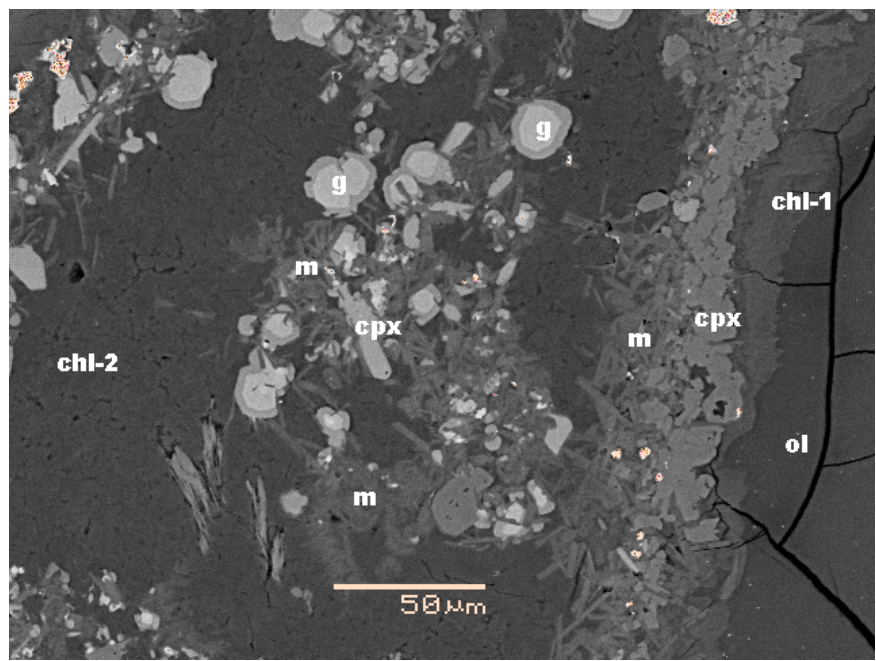


Figure 12. Interclast matrix, Letseng KPK.

Commonly, the interclast matrix in the Letseng K1-KPK con tains abundant sprays of prismatic pectolite (p). Its presence, together with hydro-andradite-grossular (g) suggests contamination of the magma forming the interclast matrix.. Note that fresh phlogopite is present within the interclast chlorite (chl-3) mesostasis.

Macrocrystal olivine forming the cores to the magm aclasts are pseudom orph ed by two generation s of chlorite (chl-1;chl-2) that are more aluminous than chlorite- 3 .

The macrocryst in the upper part of the figure contains abundant euhedral perovskite (pv) at the margin of the crystal

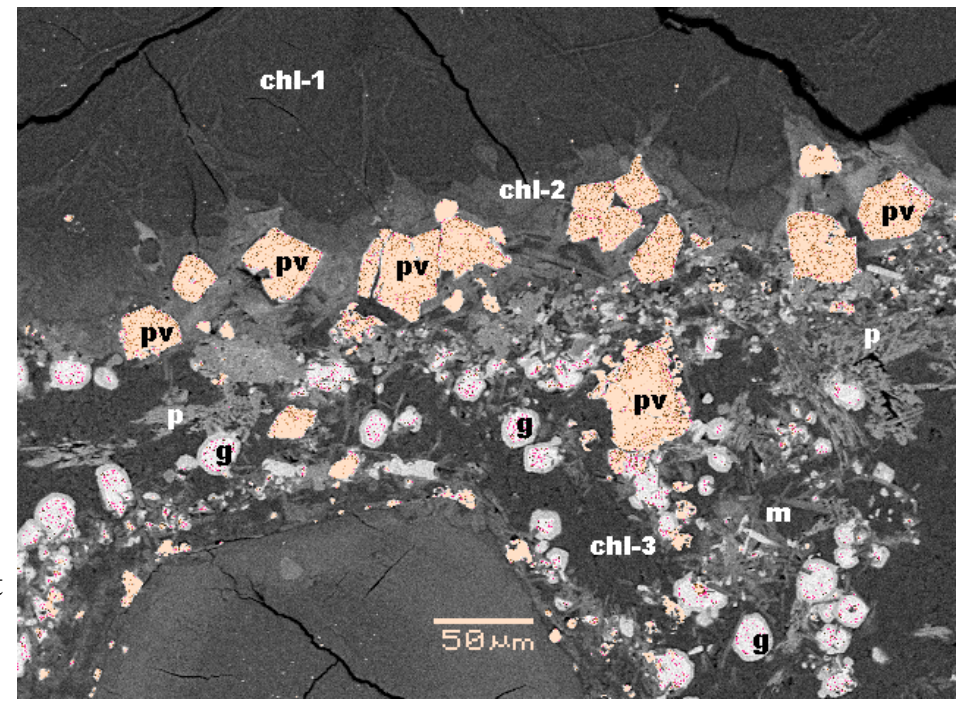

Figure 12

\section{PREMIER GREY KIMBERLITE}

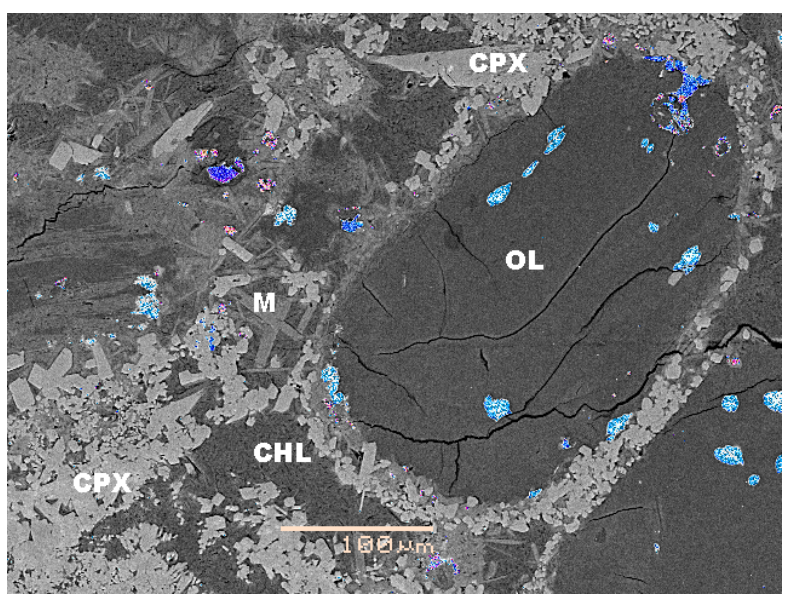

Figure 13

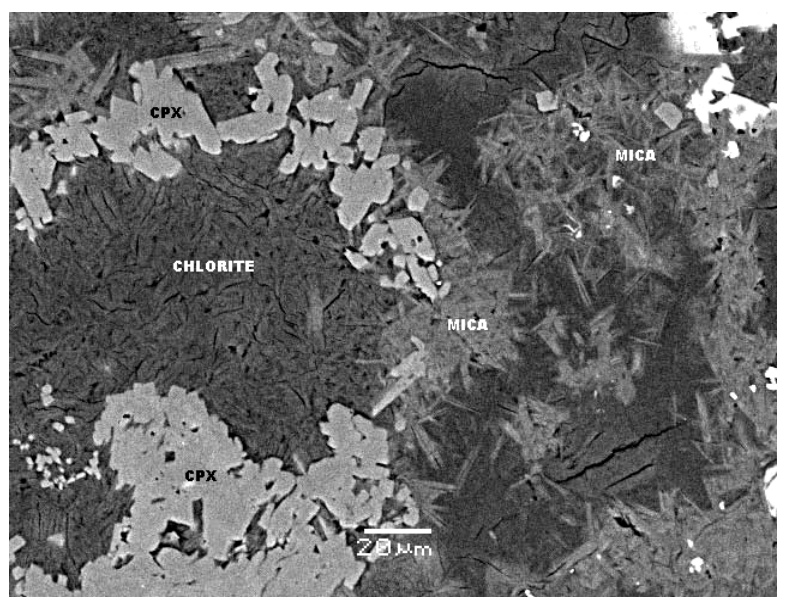

Figure 14

Figure 13. Diopside-rich (cpx) interclast matrix in Premier Grey KPK with late-forming fresh phlogopite. Also present is spinel (blue).

Figure 14. Inter clast matrix in Premier grey KPK with diopside (cpx) and later -forming fresh phlogopite being tran sformed to K-bearing chlorite and ultimately to Al-chlorite. The relationships suggests that the interclast matrix was origin ally phlogopit e-rich. None of these pha ses are consider ed to be secondary minerals replacin $g$ inter-clast a sh or glass.

Clement, CR. 1973. Kimberlites from the Kao pipe, Lesotho. In: Nixon, PH(ed). Lesotho Kimberlites. Lesotho National Development Corp. Maseru, pp. 110-121/

Mitchell, RH., Skinner, EMW, Scott Smith, BH. 2009. Tuffi sitic kimberlites from the Wesselton Mine, South Africa: Mineralogical Characteristics relevant to their formation. Lith os 112S, 452-464 